\title{
Effects of BMP-2 Delivery in Calcium Phosphate Bone Graft Materials with Different Compositions on Bone Regeneration
}

\author{
Jin-Chul Park ${ }^{1,+}$, Eun-Bin Bae ${ }^{2,+}$, Se-Eun Kim ${ }^{3,+}{ }^{\text {, So-Yun Kim }}{ }^{4}$, Kyung-Hee Choi ${ }^{5}$, \\ Jae-Won Choi ${ }^{2}$, Ji-Hyeon Bae ${ }^{2}$, Jae-Jun Ryu ${ }^{1, *}$ and Jung-Bo Huh ${ }^{2, *}$ \\ 1 Department of Dentistry, School of Medicine, Korea University, Seoul 02841, Korea; jinchol09@hanmail.net \\ 2 Department of Prosthodontics, BK21 PLUS Project, School of Dentistry, Pusan National University, \\ Yangsan 50612, Korea; 0228dmqls@hanmail.net (E.-B.B.); won9180@hanmail.net (J.-W.C.); \\ say0739@daum.net (J.-H.B.) \\ 3 Department of Veterinary Surgery, College of Veterinary Medicine, Chonnam National University, \\ Gwangju 61186, Korea; sen0223@gmail.com \\ 4 School of Dentistry, Pusan National University, Yangsan 50612, Korea; annasoyunkim@gmail.com \\ 5 Tissue Biotech Institute, Cowellmedi Co., Ltd., Busan 46986, Korea; ckh@cowellmedi.com \\ * Correspondence: koprosth@unitel.co.kr (J.-J.R.); neoplasia96@hanmail.net (J.-B.H.); \\ Tel.: +82-10-6749-0830 (J.-J.R.); +82-10-8007-9099 (J.-B.H.); \\ Fax: +82-02-921-7348 (J.-J.R.); +82-55-360-5134 (J.-B.H.) \\ + These authors contributed equally to this work.
}

Academic Editor: Georgios E. Romanos

Received: 28 September 2016; Accepted: 17 November 2016; Published: 23 November 2016

\begin{abstract}
This study was undertaken to investigate the effect of loading rhBMP-2 onto biphasic calcium phosphate $(\mathrm{BCP})$ and calcium pyrophosphate $(\mathrm{CPP})$ on bone regeneration, and to examine the efficacies of BCP and CPP as rhBMP-2 carriers. Specimens were divided into the BCP, CPP, $\mathrm{BCP} / \mathrm{BMP}$, and $\mathrm{CPP} / \mathrm{BMP}$ groups; $\mathrm{BCP}$ and $\mathrm{CPP}$ were in granules and not coated with rhBMP-2. $\mathrm{BCP} / \mathrm{BMP}$ and $\mathrm{CPP} / \mathrm{BMP}$ were prepared as discs, which were treated with rhBMP-2 and collagen. Physical and biological features were investigated using in-vitro and in-vivo tests. New bone area percentages (\%) in the $\mathrm{BCP} / \mathrm{BMP}$ and $\mathrm{CPP} / \mathrm{BMP}$ groups were significantly greater than in the $\mathrm{BCP}$ and CPP groups. At weeks 4 and 8 post-implantation, CPP/BMP showed the most new bone growth. Within the limitations of this study, treatment of BCP and CPP with rhBMP-2 significantly enhanced bone regeneration. CPP was found to be a suitable carrier for rhBMP-2.
\end{abstract}

Keywords: alloplast; bone substitutes; biphasic calcium phosphate; calcium pyrophosphate; rhBMP-2

\section{Introduction}

The use of biomaterials for bone regeneration has been widely utilized by dental bone augmentation procedures such as extraction socket defect grafting, sinus augmentation, and ridge augmentation [1]. Bone graft biomaterials should possess the properties of osteoconduction and osteoinduction to promote the formation of new bone [2]. Autogenic bone grafting has been traditionally used for defect reconstruction, but more recently a variety of graft materials, such as allogenic, xenogenic, and synthetic bones, have been introduced [3,4]. Autogenic bone is the most ideal graft material due to its outstanding biocompatibility, bone formation ability, osteoinductivity, and osteoconductivity. However, available amounts are limited, its resorption pattern is difficult to predict, and the additional surgery for harvesting causes patient discomfort and introduces risks of possible complications [3-5]. Allogenic and xenogenic bones are obtained from corpses and animals, respectively, and thus, no harvesting is required and availability is not an issue, but immune rejection 
and cross infection are possible [6]. Accordingly, alloplast grafting is becoming increasingly popular, and calcium phosphates are commonly used because their chemical compositions are similar to that of natural bone [7-11].

Hydroxyapatite $\left(\mathrm{Ca}_{5}\left(\mathrm{PO}_{4}\right)_{3}(\mathrm{OH})\right.$ or $\left.\mathrm{HA}\right), \beta$-tricalcium phosphate $\left(\mathrm{Ca}_{3}\left(\mathrm{PO}_{4}\right)_{2}\right.$ or $\beta$-TCP), and calcium pyrophosphate $\left(\mathrm{Ca}_{2} \mathrm{P}_{2} \mathrm{O}_{7}\right.$ or $\left.\mathrm{CPP}\right)$ are representative of calcium phosphates used as biological graft materials [12]. HA is widely used due to its excellent biocompatibility and osteoconductivity in dentistry [12,13], but its biodegradability is poor, as such, the graft material remains in defects for a long period of time and ultimately blocks new bone formation $[14,15]$. The effort to improve the degradation rate of HA through granting porosity faces a limitation since it results in weaker compressive strength unsuitable for load-bearing application [16]. The $\beta$-TCP has a faster in vivo degradation rate than HA but its mechanical properties are inferior, and thus, biphasic calcium phosphate (BCP; a mixture of $\mathrm{HA}$ and $\beta$-TCP) is used $[3,17]$. On the other hand, the degradation rate of calcium pyrophosphate (CPP) is faster than those of $\beta$-TCP and HA, and positive results have been reported in terms of space maintenance when CPP was used alone $[18,19]$. Consequently, CPP is considered a near ideal alloplast. The outstanding biocompatibility of CPP with bone tissue has been verified in-vitro and in-vivo [10,20]. In one study, in which CPP was applied to tibial metaphyses of rats and rabbits, the biodegradability and new bone formation ability of CPP were found to be comparable to those of HA [8-10]. An ideal bone substitute plays a role as a focus for new bone formation during resorption [21]; when CPP is grafted into a bone defect, new bone formation occurs underneath the graft $[8,10,11]$. Kitsug et al. [9] observed direct contact between CPP and bone using transmission electron microscopy (TEM), and no interposition of soft tissue. Despite of the reported advantages of CPP, it has not been widely used as a bone substitute because when CPP degrades it releases pyrophosphate $\left(\mathrm{P}_{2} \mathrm{O}_{7}{ }^{4-}\right)$ which inhibits HA formation [22]. However, recent studies have shown alkaline phosphatase (ALP), which is secreted by osteoblasts, hydrolyzes pyrophosphate and prevents it inhibiting HA formation, and that the phosphate $\left(\mathrm{PO}_{4}{ }^{-}\right)$produced fosters mineralization. Thus, it appears CPP can be utilized as a bone substitute [23].

The use of synthetic bone in clinical practice is limited by lack of osteoinductivity [24]. Osteoinductive proteins, such as recombinant human bone morphogenetic protein-2 (rhBMP-2), promote the differentiation of mesenchymal stem cells (MSCs) and pre-osteoblast into osteoblasts and trigger the migration of osteoblasts $[25,26]$. Recent clinical and histological studies have demonstrated the addition of rhBMP-2 during bone grafting improves results [27,28], and another study reported that injection of rhBMP-2 induced orthotopic and ectopic bone formation [29]. Furthermore, it has been shown rhBMP-2 presents a low risk of adverse immune system reactions [30].

Some studies have confirmed rhBMP-2 has a favorable effect on new bone formation when used in conjunction with $\mathrm{BCP}$ or HA for the rehabilitation of alveolar defects [24,31]. However, no study has yet investigated the rhBMP-2/CPP combination even though CPP degrades faster than $\beta$-TCP or HA and has a porous architecture that could be used to deliver rhBMP-2 [18]. In the present study, we investigated the effect of loading rhBMP-2 into calcium phosphate bone graft materials with different compositions (BCP and $\mathrm{CPP}$ ) on bone regeneration and evaluated the feasibility of using $\mathrm{BCP}$ or CPP as rhBMP-2 carriers.

\section{Results}

\subsection{Observations of Surface Morphology}

SEM analysis was used to determine pore sizes and examine surface morphologies (Figure 1). BCP had a pore size of $0.1 \mu \mathrm{m}-1 \mu \mathrm{m}$ (Figure 1e), whereas CPP had a pore size of $10 \mu \mathrm{m}-100 \mu \mathrm{m}$ (Figure 1f). rhBMP-2 with collagen covered the surfaces of BCP/BMP (Figure 1g) and CPP/BMP (Figure 1h). 

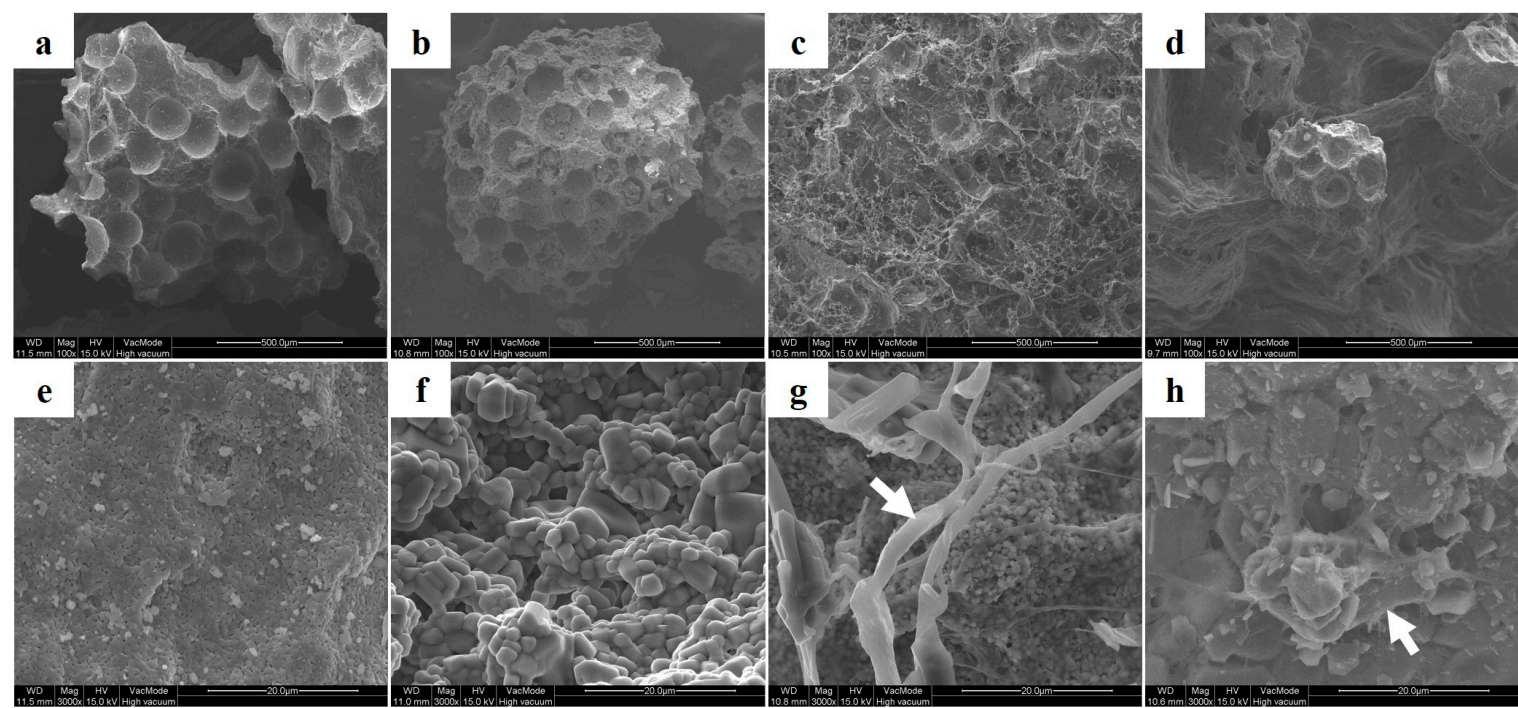

Figure 1. Scanning electron microscopic photographs of $(\mathbf{a}, \mathbf{e})$ biphasic calcium phosphate (BCP) granules; $(\mathbf{b}, \mathbf{f})$ calcium pyrophosphate (CPP) granules; $(\mathbf{c}, \mathbf{g})$ a BCP/BMP disc; $(\mathbf{d}, \mathbf{h})$ a CPP/BMP disc. White arrow: rhBMP-2 coated collagen (Original magnification $\times 100$ for $\mathbf{a}$ to $\mathbf{d}$ and $\times 3000$ for $\mathbf{e}$ to $\mathbf{h}$ ).

\subsection{Release Kinetics of RhBMP-2}

In terms of the accumulated amounts of rhBMP-2 released, the release kinetics of rhBMP-2 from $\mathrm{BCP} / \mathrm{BMP}$ and CPP/BMP are shown in Figure 2. BCP/BMP, which contained $0.4 \mu \mathrm{g}$ of rhBMP-2, released $142.68 \mathrm{ng}$ of rhBMP-2, and CPP/BMP released $299.57 \mathrm{ng}$ in 14 days. On the first day, $90 \%$ of the total amount of rhBMP-2 released in 2 weeks was rapidly discharged from both BCP/BMP and $\mathrm{CPP} / \mathrm{BMP}$, with values of $130.28 \mathrm{ng}$ and $282.85 \mathrm{ng}$, respectively.

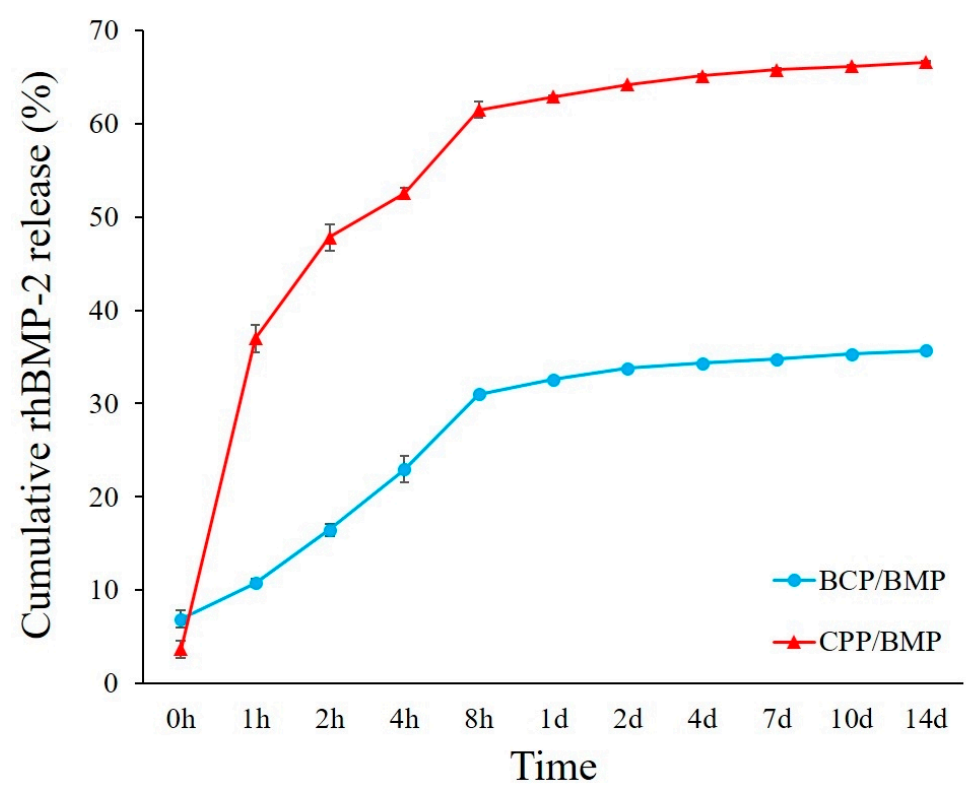

Figure 2. Release kinetics of rhBMP-2. CPP/BMP released double the amount of rhBM-2 than $\mathrm{BCP} / \mathrm{BMP}$.

\subsection{Observation of Cell Attachment}

In order to observe cell attachment profiles on the different graft materials, $\mathrm{C} 2 \mathrm{C} 12$ cells were introduced to each experimental group and cultured for 14 days. In BCP and BCP/BMP, attached 
cells were spread over surfaces (Figure 3a,c), whereas in CPP and CPP/BMP, cells formed colonies (Figure 3b,d).
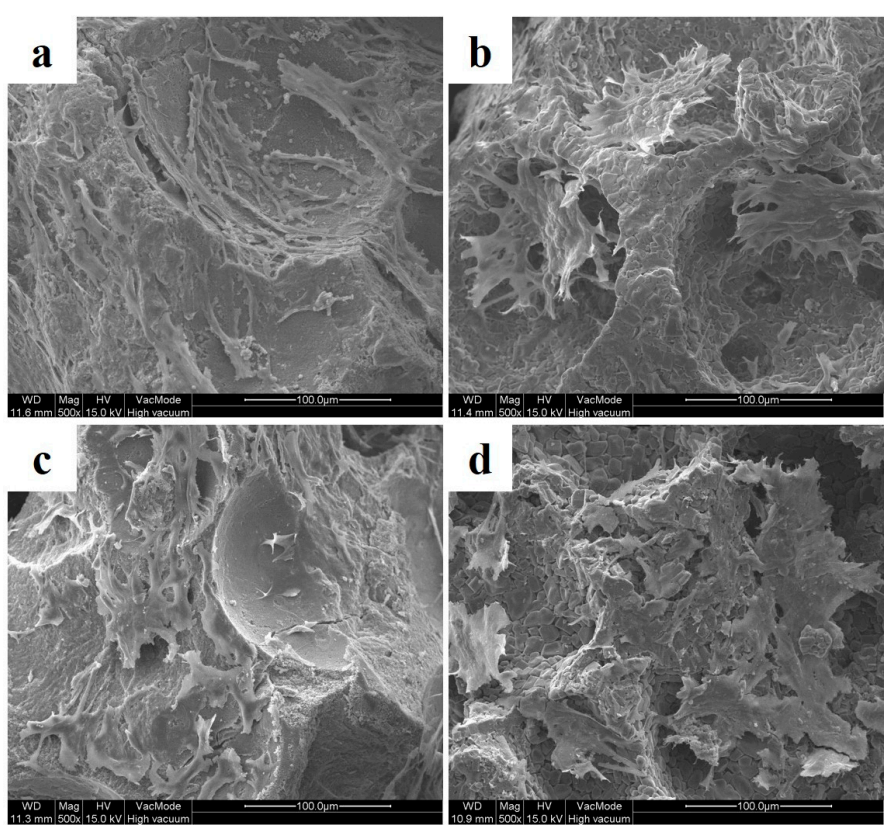

Figure 3. SEM photographs of graft material surfaces after culture with $\mathrm{C} 2 \mathrm{C} 12$ for 14 days. (a) $\mathrm{BCP}$ granule; (b) CPP granule; (c) BCP/BMP granule; and (d) CPP/BMP granule (original magnification $\times 500$ ).

\subsection{Measurement of Cell Proliferation}

Cell proliferations in the control and experimental cultures are shown in Figure 4a. At day 1, 3 , and 7 , no difference was observed between any of the groups (Figure 4a), indicating none of the materials were cytotoxic.

(a)

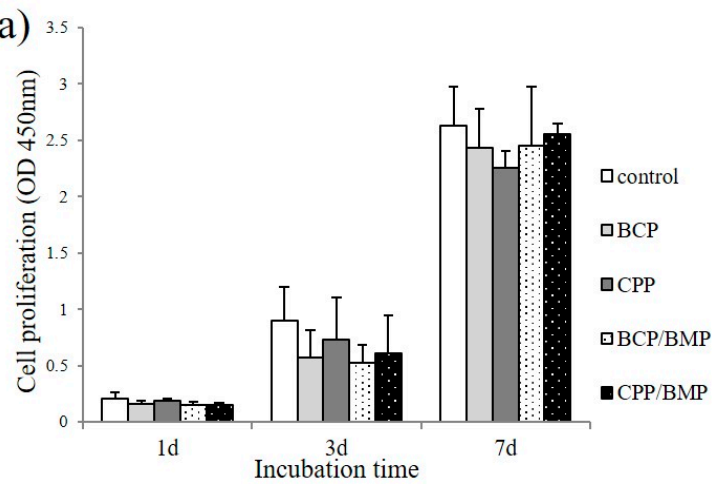

(b)

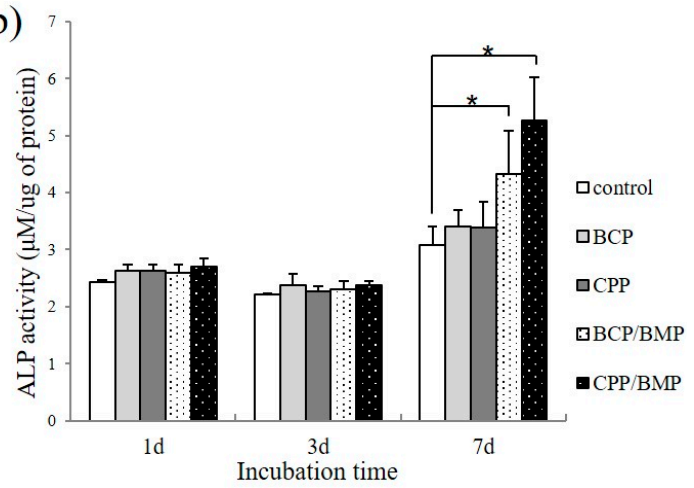

Figure 4. (a) Proliferation and (b) Alkaline phosphatase (ALP) activity of myoblast cells (C2C12 cells)

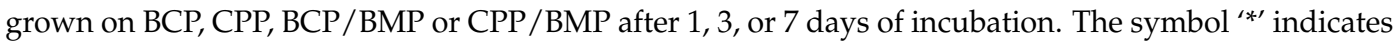
significantly different versus the control $(p<0.05)$.

\subsection{Measurement of Alkaline Phosphatase (ALP) Activity}

The levels of ALP activity in control and experimental cultures are shown in Figure 4b. On days 1 and 3, ALP activities were similar in the experimental and control groups. However, on day 7, BCP / BMP showed significantly higher ALP activity than the control $(p<0.05)$, and CPP/BMP yielded significantly higher activity than the control, $\mathrm{BCP}$, and CPP groups $(p<0.05)$. 


\subsection{Histologic Findings in Animal Study}

Images of histological sections of the control and experimental groups were prepared at week 4 and week 8 post-implantation (Figure 5). The control showed minor new bone formation at both times and a small amount of fibrous tissue. Both BCP and CPP exhibited fibrous tissue around graft materials on week 4 , and small amounts of new bone formation on week 8. BCP/BMP and CPP/BMP displayed a small amount of new bone formation around the graft materials on week 4 and more new bone formation on week 8 .

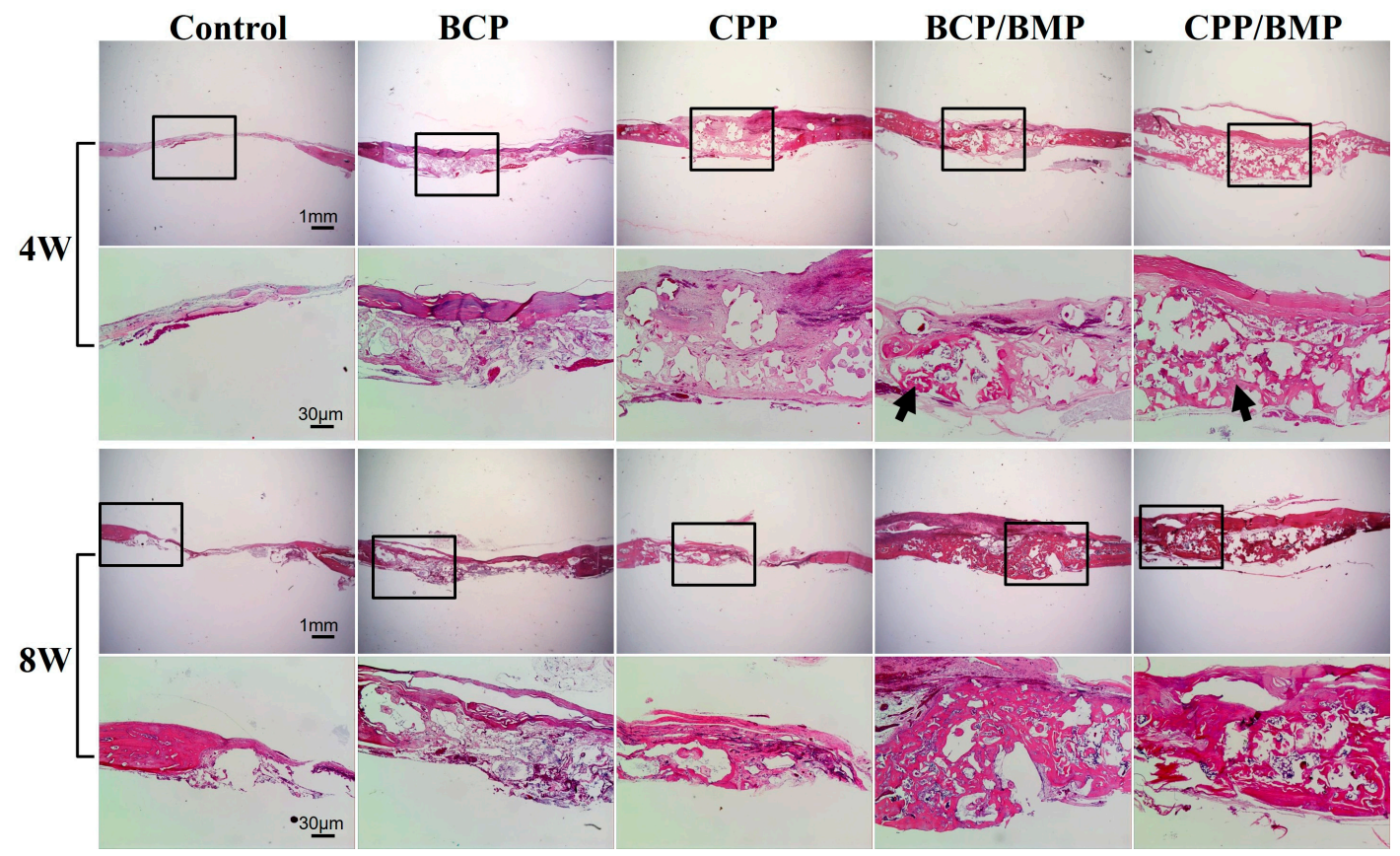

Figure 5. Hematoxylin and eosin staining of histological sections of defect sites at 4 and 8 weeks' post-implantation. Black arrow; newly formed bone (original magnification: $\times 12.5$ for rows 1 and 3 , and $\times 40$ for rows 2 and 4 ).

\subsection{Histometric Findings in Animal Study}

New bone densities (\%) are shown in Figure 6. On weeks 4 and 8, the BCP and CPP groups were not significantly different than the control group $(p>0.05)$, but the experimental groups showed significantly greater new bone densities than the control, $\mathrm{BCP}$, and CPP groups $(p<0.05)$. As compared to new bone densities measured at week 4, the control, BCP, CPP, and CPP/BMP groups did not exhibit a significant increase at week $8(p>0.05)$. However, the BCP/BMP group demonstrated a significant increase in new bone density at week $8(p<0.05)$. New bone formation was significantly greater in the CPP/BMP group than in the BCP/BMP group at 4 weeks $(p<0.05)$ but not at 8 weeks $(p>0.05)$. 


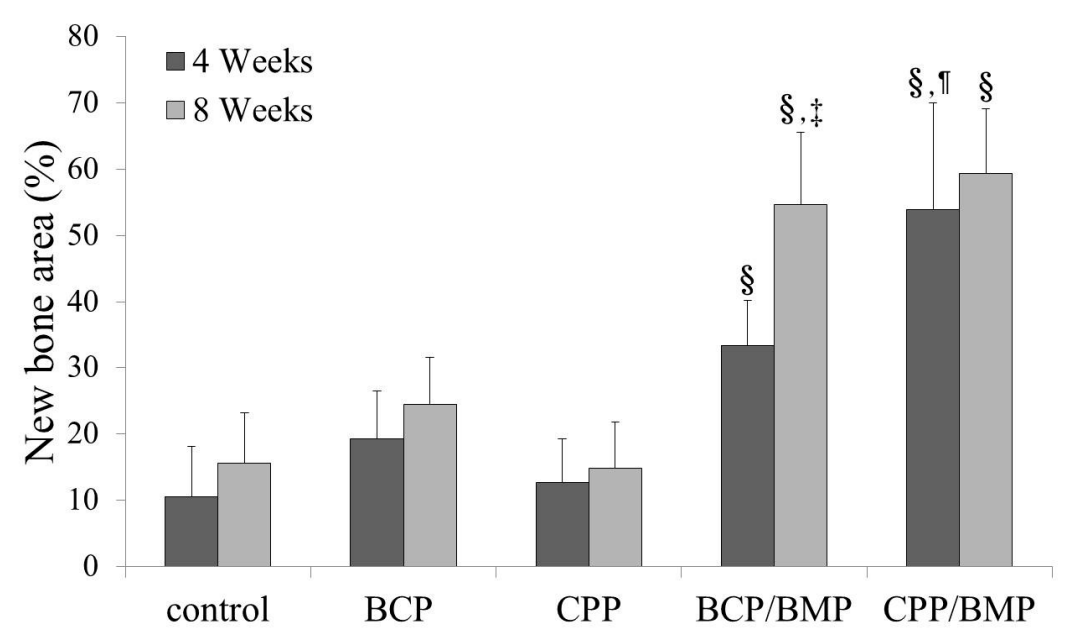

Figure 6. New bone area percentages at 4 and 8 weeks' post-implantation. No significant differences were found between the control, BCP, and CPP groups at 4 or 8 weeks. The symbol ' $\$$ ' indicates significantly higher percentage versus the control, BCP, and CPP groups at the indicated time $(p<0.05)$. The symbol 'II' indicates significantly higher percentage versus BCP/BMP group at the indicated time $(p<0.05)$. ' $f$ ' indicates significantly higher percentage versus the same group at 4 weeks $(p<0.05)$.

\section{Discussion}

An ideal bone graft material should have sufficient strength and stability as a scaffold to promote new bone, function as a channel for osteoinductive materials, degrade optimally, and be replaced by new bone [32,33]. As reported previously, CPP induces a biological response similar to those of HA and has excellent biodegradability. Sun et al. [20] verified an outstanding bioactivity of CPP by demonstrating the oral administration of CPP to ovariectomized rats restricted an increase in bony trabecular porosity and promoted bone mineralization in long bones. Moreover, physical properties including particle size, crystallinity, porosity, and surface roughness, and chemical properties including $\mathrm{Ca} / \mathrm{P}$ ratio and $\mathrm{pH}$ affect the bioactivities and biodegradabilities of bone graft materials. Furthermore, several studies have investigated the effect of different $\mathrm{Ca} / \mathrm{P}$ ratios on bone regeneration $[34,35]$. In the present study, $\mathrm{CPP}$ with $\mathrm{Ca} / \mathrm{P}$ ratio of 1 was compared with $\mathrm{BCP}$ with $\mathrm{Ca} / \mathrm{P}$ ratio of 1.55 , the most common graft material in clinical practice. In recent years, numerous studies have incorporated growth factors, such as, rhBMP-2, with various bone graft biomaterials to enhance bone regeneration [24]. The bone regeneration capacity of rhBMP-2 is dependent on carrier type [36,37], and a good carrier should load protein easily, secure a space for regeneration, and exhibit bioabsorbable and bioactive degradation. In the present study, two alloplasts, BCP and CPP, were loaded with rhBMP-2 to examine their feasibilities as compatible rhBMP-2 carriers.

The two bone graft materials examined in the present study had rhBMP-2 release behaviors similar to those reported by Boyne et al [38], that is, BCP/BMP and CPP/BMP released more than $90 \%$ of their total release amounts within one day, and these rapid releases seemed to be responsible for the ineffectiveness of rhBMP-2 to induce new bone formation in clinical applications. To facilitate the sustained release of rhBMP-2, Huh et al. [39] attempted to chemically immobilize rhBMP-2 to DOPA-heparin on xenogenous bone. However, the chemical approach is challenging clinically and potential chemical toxicity restricts its clinical application. Accordingly, in the present study, we used a physical coating technique and avoided the use of any chemical functional group. Even though bone graft materials were coated physically, the different graft materials exhibited different release rate patterns, that is, $\mathrm{CPP} / \mathrm{BMP}$ showed a higher accumulation rate than $\mathrm{BCP} / \mathrm{BMP}$, which was probably due to enhanced rhBMP-2 release caused by the higher degradation rate of CPP.

Numerous studies reported that bone substitute surface roughness affects cell adhesion and morphology [40,41]. Using SEM images of C2C12 cells, we confirmed that cell morphologies depended 
on bone substitute surface roughness rather than on the presence of growth factor in the BCP and $\mathrm{BCP} / \mathrm{BMP}$ groups and in the CPP and CPP/BMP groups, but BCP and CPP containing groups differed. Furthermore, $\mathrm{C} 2 \mathrm{C} 12$ cells in $\mathrm{CPP}$ proliferated more than in $\mathrm{BCP}$, but the difference was not significant. Such difference in proliferation are due to the preference of cells for a rough surface, which is consistent with a report issued by Deligianni et al. [40].

As observed through histometric analysis, CPP/BMP exhibited significantly greater new bone formation than $\mathrm{BCP} / \mathrm{BMP}$ at 4 weeks' post-implantation, and this fast degradation rate of $\mathrm{CPP}$ increased the rate of rhBMP-2 release, and better promoted an early stage of new bone formation. Alam et al. [34] demonstrated that rapidly degraded bone graft materials create microenvironments that favor new bone formation. However, at 8 weeks, CPP/BMP and BCP/BMP did not show significant difference. This outcome can be explained by the gradual progress in new bone formation of BCP/BMP which initially released less rhBMP-2. On the other hand, new bone formation was not promoted in the BCP and CPP groups.

In the present study, BCP/BMP and CPP/BMP induced new bone formation and did not induce inflammatory responses, which is indicative of their biocompatibilities and potential as suitable rhBMP-2 carriers. However, it should be borne in mind that this in-vivo study was conducted using a small number of samples and observations at 4 and 8 weeks' post-implantation, and therefore, we suggest further larger-scale, more comprehensive longitudinal studies be conducted. Furthermore, due to its hydrophilicity, rhBMP-2 should be delivered to targeted sites, and thus, studies are also required to optimize the method of rhBMP-2 loading and to determine its optimal dose and concentration.

\section{Materials and Methods}

\subsection{Preparation of Porous Calcium Phosphate Coated with RhBMP-2}

BCP granules (particle size $0.4 \mathrm{~mm}-1.0 \mathrm{~mm}$, Cowellmedi, Busan, Korea) were prepared by sintering biphasic calcium phosphate powder (HA/ $\beta$-TCP: 3/7; Figure 7a). CPP (particle size $0.4 \mathrm{~mm}-1.0 \mathrm{~mm}$; Cowellmedi, Busan, Korea) was prepared by sintering dicalcium phosphate powder (Figure $7 \mathrm{~b}$ ). To prepare BCP/BMP and CPP/BMP, $0.3 \mathrm{~mL}$ of collagen (Cowellmedi, Busan, Korea) was added per $0.1 \mathrm{~g}$ of BCP or CPP granules. The mixture so obtained was freeze-dried to produce $1 \mathrm{~mm}$ thick discs of diameter $8 \mathrm{~mm}$. Each disc was treated with $100 \mu \mathrm{L}$ of rhBMP-2 solution, which was equivalent to a loading of $5 \mu \mathrm{g}$ of rhBMP-2/ disc, and then freeze-dried.

(a)

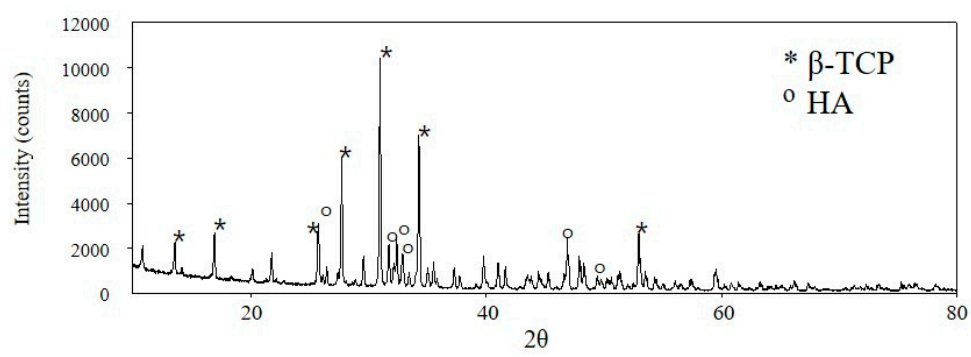

(b)

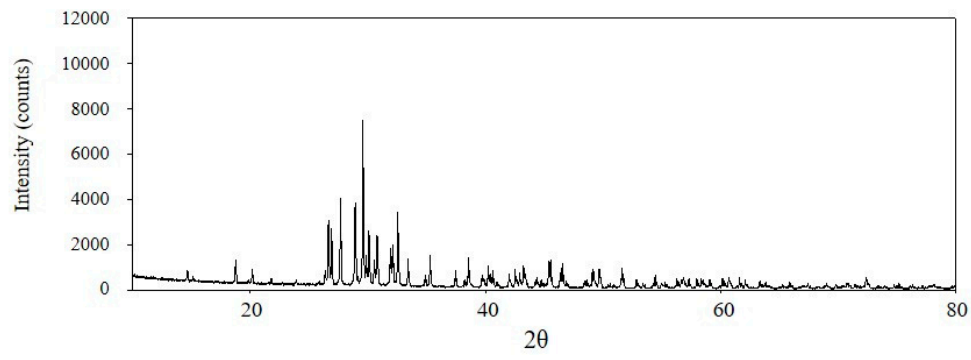

Figure 7. X-ray diffraction analysis (XRD) patterns of bone graft materials. (a) BCP containing HA(30): $\beta$-TCP(70); (b) CPP. 


\subsection{Release Kinetics of rhBMP-2}

$\mathrm{BCP} / \mathrm{BMP}$ and $\mathrm{CPP} / \mathrm{BMP}$ were placed to $1 \mathrm{~mL}$ of phosphate-buffered saline $(\mathrm{pH}=7.4)$ containing $0.02 \%$ sodium azide and agitated in a shaking incubator at $37^{\circ} \mathrm{C}$ and $200 \mathrm{rpm}$. Supernatants were collected, and a fresh $1 \mathrm{~mL}$ of PBS was added up to 14 days. Concentrations of rhBMP-2 in supernatants were determined using a human BMP-2 ELISA kit (Pepro Tech, Rocky Hill, NJ, USA) and absorbances were measured using a microplate reader at $495 \mathrm{~nm}$.

\subsection{Observations of Cell Attachment}

In order to investigate cell attachments to different bone graft materials, a 48-well culture plate was prepared as mentioned in Section 2.3 using the same medium used for cell proliferation (medium was replaced every 3 days) and cultured under $5 \% \mathrm{CO}_{2}$ at $37^{\circ} \mathrm{C}$ for 14 days.

\subsection{Measurement of Cell Proliferation}

$\mathrm{C} 2 \mathrm{C} 12$ myoblasts $\left(1.5 \times 10^{4}\right.$ cells/well) were loaded into a 48-well culture plate, and then $0.01 \mathrm{~g}$ of $\mathrm{BCP}, \mathrm{CPP}, \mathrm{BCP} / \mathrm{BMP}$, or CPP/BMP was added. The plate was cultured under $5 \% \mathrm{CO}_{2}$ at $37^{\circ} \mathrm{C}$ for 1, 3, or 7 days. Dulbecco's Modified Eagle's Medium (DMEM) containing 10\% FBS, $100 \mathrm{U} / \mathrm{mL}$ Penicillin, and $100 \mu \mathrm{g} / \mathrm{mL}$ Streptomycin was used as the culture medium. The control was prepared in an identical manner but without bone graft material. After culture, cells were counted using the Cell Counting Kit-8 (Dojindo, Tokyo, Japan).

\subsection{Measurement of Alkaline Phosphatase Activity (ALP)}

A 48-well culture plate containing C2C12 myoblasts was prepared and cultured as described above. For ALP activity measurements, medium was removed, and cells were separated with trypsin-EDTA and harvested by centrifugation. Cells were lysed using Lysis buffer $(0.1 \%$ Triton X-100, $150 \mathrm{mM} \mathrm{NaCl}$, $50 \mathrm{mM}$ Tris, $\mathrm{pH}=8.0$ ) with sonication, and supernatants were collected by centrifugation. Protein concentrations were measured using Braford protein assay reagent at $595 \mathrm{~nm}$, including that of the standard, BSA solution. $p$-Nitrophenyl phosphate ( $p$-NPP) was used as the substrate for alkaline phosphatase. The mixture was allowed to react for $20 \mathrm{~min}, 100 \mu \mathrm{L}$ of $\mathrm{NaOH}$ (1M, Daejungchem, Seoul, Korea) was added to stop the reaction, and then ALP activity was measured at $405 \mathrm{~nm}$. ALP activity was recorded in $\mu \mathrm{M} / \mu \mathrm{g}$ of protein.

\subsection{In-Vivo Animal Study}

Fifty Sprague-Dawley rats (male, weight 250 g-300 g) were used in the study. Animals were housed individually under standard laboratory conditions in plastic cages and had ad libitum access to water and standard laboratory pellets. Animal selection, management, the surgical protocol, and preparation were approved beforehand by the Ethics Committee on Animal Experimentation at the Korea Atomic Energy Institute (KAERI-IACUC-004).

Surgical procedures were performed under general anesthesia induced by intramuscular injection. The surgical site was incised and a full-thickness flap was elevated. A standard, circular, transosseous defect of $8 \mathrm{~mm}$ in diameter was formed in the middle of calvarias using a trephine bur (3i Implant Innovations Inc., Palm Beach Garden, FL, USA). Treatments were performed after removing the trephined bony disk. Ten rats were assigned to each of the five study groups. Animals in the control group did not receive any treatment while animals in the four experiment groups $(\mathrm{BCP}, \mathrm{CPP}, \mathrm{BCP} / \mathrm{BMP}$, and $\mathrm{CPP} / \mathrm{BMP}$ groups) received one specimen covered with a collagen membrane (GENOSS, Suwon, Korea) (Figure 8a). Five rats per group were sacrificed at 4 weeks' post-implantation and the other five were sacrificed at 8 weeks.

After decalcifying calvarias with 14\% EDTA, they were further decalcified using Rapid acid decal (Calci-clear rapid, National diagnostics, Atlanta, GA, USA). The middle of each paraffin-embedded calvarial defect was sectioned at $5 \mu \mathrm{m}$, and two of the most central sections from each block were 
stained with hematoxylin and eosin. To determine areas of new bone and of residual biomaterials, we used an image analysis program (Image-Pro Plus, Media Cybernetic, Silver Spring, MD, USA). New bone areas were calculated as percentages (refer to Figure $8 b$ ).

(a)

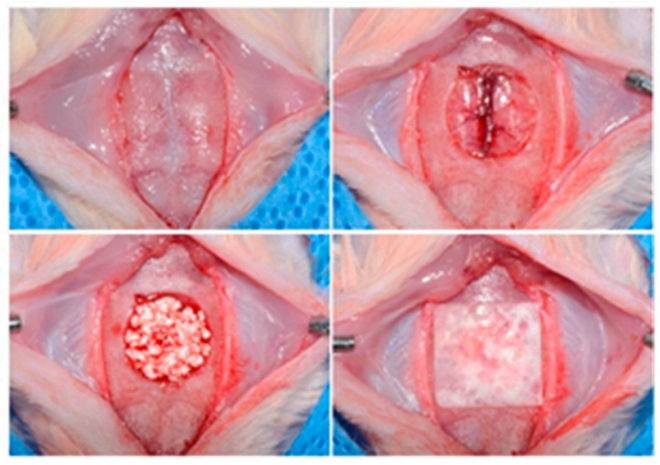

(b)

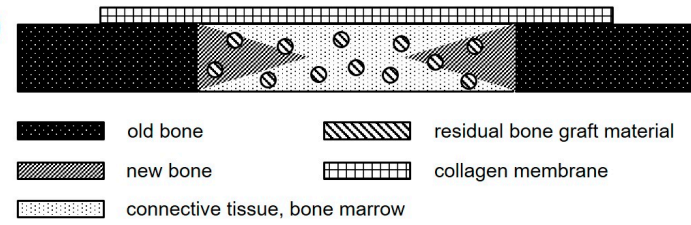

new bone area $\left(\mathrm{mm}^{2}\right)=n$

residual graft materials $\left(\mathrm{mm}^{2}\right)=m$

connective tissue, bone marrow $\left(\mathrm{mm}^{2}\right)=$

augmented area $\left(\mathrm{mm}^{2}\right)=n+m+l$

New bone area percentage $(\%)=\frac{n}{n+m+l} \times 100$

Figure 8. (a) Surgical procedures; (b) a schematic of the histometric analysis.

\section{Conclusions}

Bone morphogenetic protein-2 treated $\mathrm{BCP}$ or CPP significantly enhanced bone regeneration, and CPP was found to be a suitable carrier of rhBMP-2.

Acknowledgments: This study was supported by a research grant (2 years) from Pusan National University, South Korea.

Author Contributions: Jung-Bo Huh and Jae-Jun Ryu conceived and designed the experiments; Jin-Chul Park, Eun-Bin Bae, Se-Eun Kim, So-Yun Kim, Kyung-Hee Choi, Jae-Won Choi and Ji-Hyeon Bae performed the experiments; Jin-Chul Park, Eun-Bin Bae and Se-Eun Kim analyzed the data; Kyung-Hee Choi contributed reagents; Eun-Bin Bae and Jung-Bo Huh wrote the paper.

Conflicts of Interest: The authors have no conflict of interest to declare.

\section{Abbreviations}

$\begin{array}{ll}\text { HA } & \text { Hydroxyapatite } \\ \beta \text {-TCP } & \beta \text {-tricalcium phosphate } \\ \text { BCP } & \text { Biphasic calcium phosphate } \\ \text { CPP } & \text { Calcium pyrophosphate } \\ \text { TEM } & \text { Transmission electron microscope } \\ \text { ALP } & \text { Alkaline phosphatase } \\ \text { RhBMP-2 } & \text { Recombinant human bone morphogenetic protein-2 } \\ \text { SEM } & \text { Scanning electron microscope }\end{array}$

\section{References}

1. McAllister, B.S.; Haghighat, K. Bone augmentation techniques. J. Periodontol. 2007, 78, 377-396. [CrossRef] [PubMed]

2. Maté Sánchez de Val, J.E.; Calvo Guirado, J.L.; Ramírez Fernández, M.P.; Delgado Ruiz, R.A.; Mazón, P.; de Aza, P.N. In vivo behavior of hydroxyapatite/ $\beta$-TCP/collagen scaffold in animal model. Histological, histomorphometrical, radiological, and SEM analysis at 15, 30, and 60 days. Clin. Oral Implant. Res. 2015. [CrossRef]

3. Greenwald, A.S.; Boden, S.D.; Goldberg, V.M.; Khan, Y.; Laurencin, C.T.; Rosier, R.N. Bone-graft substitutes: Facts, fictions, and applications. J. Bone Jt. Surg. Am. 2001, 83, 98-103. [CrossRef]

4. Bauer, T.W.; Muschler, G.F. Bone graft materials. An overview of the basic science. Clin. Orthop. Relat. Res. 2000, 371, 10-27. [CrossRef]

5. Clavero, J.; Lundgren, S. Ramus or chin grafts for maxillary sinus inlay and local onlay augmentation: Comparison of donor site morbidity and complications. Clin. Implant Dent. Relat. Res. 2003, 5, 154-160. [CrossRef] [PubMed] 
6. Ghanaati, S.; Barbeck, M.; Booms, P.; Lorenz, J.; Kirkpatrick, C.J.; Sader, R.A. Potential lack of “standardized” processing techniques for production of allogeneic and xenogeneic bone blocks for application in humans. Acta Biomater. 2014, 10, 3557-3562. [CrossRef] [PubMed]

7. Bernhardt, A.; Lode, A.; Peters, F.; Gelinsky, M. Comparative evaluation of different calcium phosphate-based bone graft granules-An in vitro study with osteoblast-like cells. Clin. Oral Implant. Res. 2013, 24, 441-449. [CrossRef] [PubMed]

8. Kitsugi, T.; Yamamuro, T.; Nakamura, T.; Kotani, S.; Kocubo, T.; Takeuchi, H. Four calcium phosphate ceramics as bone substitutes for non-weight-bearing. Biomaterials 1993, 14, 216-224. [CrossRef]

9. Kitsugi, T.; Yamamuro, T.; Nakamura, T.; Oka, M. Transmission electron microscopy observations at the interface of bone and four types of calcium phosphate ceramics with different calcium/ phosphorus molar ratios. Biomaterials 1995, 16, 1101-1107. [CrossRef]

10. Lin, F.H.; Lin, C.C.; Lu, C.M.; Liu, H.C.; Sun, J.S.; Wang, C.Y. Mechanical properties and histological evaluation of sintered $\beta-\mathrm{Ca}_{2} \mathrm{P}_{2} \mathrm{O}_{7}$ with $\mathrm{Na}_{4} \mathrm{P}_{2} \mathrm{O}_{7} \cdot 10 \mathrm{H}_{2} \mathrm{O}$ addition. Biomaterials 1995, 16, 793-802. [CrossRef]

11. Lin, C.C.; Liao, C.J.; Sun, J.S.; Liu, H.C.; Lin, F.H. Prevascularized bone graft cultured in sintered porous $\beta-\mathrm{Ca}_{2} \mathrm{P}_{2} \mathrm{O}_{7}$ with 5 wt $\% \mathrm{Na}_{4} \mathrm{P}_{2} \mathrm{O}_{7} \cdot 10 \mathrm{H}_{2} \mathrm{O}$ addition ceramic chamber. Biomaterials 1996, 17, 1133-1140. [CrossRef]

12. Misch, C.E.; Dietsh, F. Bone-grafting materials in implant dentistry. Implant Dent. 1993, 2, 158-167. [CrossRef] [PubMed]

13. Holmes, R.E.; Bucholz, R.W.; Mooney, V. Porous hydroxyapatite as a bone graft substitute in diaphyseal defects: A histometric study. J. Orthop. Res. 1987, 5, 114-121. [CrossRef] [PubMed]

14. Barralet, J.; Akao, M.; Aoki, H.; Aoki, H. Dissolution of dense carbonate apatite subcutaneously implanted in Wistar rats. J. Biomed. Mater. Res. 2000, 49, 176-182. [CrossRef]

15. Chissov, V.I.; Sviridova, I.K.; Sergeeva, N.S.; Frank, G.A.; Kirsanova, V.A.; Achmedova, S.A.; Reshetov, I.V.; Filjushin, M.M.; Barinov, S.M.; Fadeeva, I.V.; et al. Study of in vivo biocompatibility and dynamics of replacement of rat shin defect with porous granulated bioceramic materials. Bull. Exp. Biol. Med. 2008, 146, 139-143. [CrossRef] [PubMed]

16. Sun, F.; Zhou, H.; Lee, J. Various preparation methods of highly porous hydroxyapatite/polymer nanoscale biocomposites for bone regeneration. Acta Biomater. 2011, 7, 3813-3828. [CrossRef] [PubMed]

17. Nevins, M.; Nevins, M.L.; Schupbach, P.; Kim, S.W.; Lin, Z.; Kim, D.M. A prospective, randomized controlled preclinical trial to evaluate different formulations of biphasic calcium phosphate in combination with a hydroxyapatite collagen membrane to reconstruct deficient alveolar ridges. J. Oral. Implantol. 2013, 39, 133-139. [CrossRef] [PubMed]

18. Klein, C.P.; Driessen, A.A.; de Groot, K.; van den Hooff, A. Biodegradation behavior of various calcium phosphate materials in bone tissue. J. Biomed. Mater. Res. 1983, 17, 769-784. [CrossRef] [PubMed]

19. Lee, J.H.; Chang, B.S.; Jeung, U.O.; Park, K.W.; Kim, M.S.; Lee, C.K. The first clinical trial of beta-calcium pyrophosphate as a novel bone graft extender in instrumented posterolateral lumbar fusion. Clin. Orthop. Surg. 2011, 3, 238-244. [CrossRef] [PubMed]

20. Sun, J.S.; Huang, Y.C.; Tsuang, Y.H.; Chen, L.T.; Lin, F.H. Sintered dicalcium pyrophosphate increases bone mass in ovariectomized rats. J. Biomed. Mater. Res. 2002, 59, 246-253. [CrossRef] [PubMed]

21. Bye, F.L.; Krause, M.E.; Regezi, J.A.; Caffesse, R.G. Histologic evaluation of periodontal implants in a biologically "closed" model. J. Periodontol. 1987, 58, 110-114. [CrossRef] [PubMed]

22. Fleisch, H.; Bisaz, S. Mechanism of calcification: Inhibitory role of pyrophosphate. Nature 1962, $195,911$. [CrossRef] [PubMed]

23. Hessle, L.; Johnson, K.A.; Anderson, H.C.; Narisawa, S.; Sali, A.; Goding, J.W.; Terkeltaub, R.; Millan, J.L. Tissue-nonspecific alkaline phosphatase and plasma cell membrane glycoprotein-1 are central antagonistic regulators of bone mineralization. Proc. Natl. Acad. Sci. USA 2002, 99, 9445-9449. [CrossRef] [PubMed]

24. Polo, C.I.; Lima, J.L.; de Lucca, L.; Piacezzi, C.B.; Naclério-Homem Mda, G.; Arana-Chavez, V.E.; Sendyk, W.R. Effect of recombinant human bone morphogenetic protein 2 associated with a variety of bone substitutes on vertical guided bone regeneration in rabbit calvarium. J. Periodontol. 2013, 84, 360-370. [CrossRef] [PubMed]

25. Urist, M.R. Bone: Formation by autoinduction. Science 1965, 15, 893-899. [CrossRef]

26. Ripamonti, U.; Reddi, A.H. Periodontal regeneration: Potential role of bone morphogenetic proteins. J. Periodontal Res. 1994, 29, 225-235. [CrossRef] [PubMed] 
27. Jung, R.E.; Glauser, R.; Schärer, P.; Hämmerle, C.H.; Sailer, H.F.; Weber, F.E. Effect of rhBMP-2 on guided bone regeneration in humans. Clin. Oral Implant. Res. 2003, 14, 556-568. [CrossRef] [PubMed]

28. Higuchi, T.; Kinoshita, A.; Takahashi, K.; Oda, S.; Ishikawa, I. Bone regeneration by recombinant human bone morphogenetic protein-2 in rat mandibular defects. An experimental model of defect filling. J. Periodontol. 1999, 70, 1026-1031. [CrossRef] [PubMed]

29. Govender, S.; Csimma, C.; Genant, H.K.; Valentin-Opran, A.; Amit, Y.; Arbel, R.; Chiron, P. Recombinant human bone morphogenetic protein-2 for treatment of open tibial fractures: A prospective, controlled, randomized study of four hundred and fifty patients. J. Bone Jt. Surg. Am. 2002, 84, 2123-2134. [CrossRef]

30. Jung, R.E.; Windisch, S.I.; Eggenschwiler, A.M.; Thoma, D.S.; Weber, F.E.; Hämmerle, C.H. A randomizedcontrolled clinical trial evaluating clinical and radiological outcomes after 3 and 5 years of dental implants placed in bone regenerated by means of GBR techniques with or without the addition of BMP-2. Clin. Oral Implant. Res. 2009, 20, 660-666. [CrossRef] [PubMed]

31. Shin, Y.S.; Seo, J.Y.; Oh, S.H.; Kim, J.H.; Kim, S.T.; Park, Y.B.; Moon, H.S. The effects of ErhBMP-2-/EGCGcoated BCP bone substitute on dehiscence around dental implants in dogs. Oral Dis. 2014, 20, 281-287. [CrossRef] [PubMed]

32. Del Fabbro, M.; Rosano, G.; Taschieri, S. Implant survival rates after maxillary sinus augmentation. Eur. J. Oral Sci. 2008, 116, 497-506. [CrossRef] [PubMed]

33. Guarino, V.; Causa, F.; Ambrosio, L. Bioactive scaffolds for bone and ligament tissue. Expert Rev. Med. Devices 2007, 4, 405-418. [CrossRef] [PubMed]

34. Alam, M.I.; Asahina, I.; Ohmamiuda, K.; Takahashi, K.; Yokota, S.; Enomoto, S. Evaluation of ceramics composed of different hydroxyapatite to tricalcium phosphate ratios as carriers for rhBMP-2. Biomaterials 2001, 22, 1643-1651. [CrossRef]

35. Raynaud, S.; Champion, E.; Bernache-Assollant, D.; Thomas, P. Calcium phosphate apatites with variable $\mathrm{Ca} / \mathrm{P}$ atomic ratio I. Synthesis, characterisation and thermal stability of powders. Biomaterials 2002, 23, 1065-1072. [CrossRef]

36. Sigurdsson, T.J.; Nygaard, L.; Tatakis, D.N.; Fu, E.; Turek, T.J.; Jin, L.; Wozney, J.M.; Wikesjö, U.M. Periodontal repair in dogs: Evaluation of rhBMP-2 carriers. Int. J. Periodontics Restor. Dent. 1996, 16, 524-537.

37. Hunt, D.R.; Jovanovic, S.A.; Wikesjö, U.M.; Wozney, J.M.; Bernard, G.W. Hyaluronan supports recombinant human bone morphogenetic protein-2 induced bone reconstruction of advanced alveolar ridge defects in dogs. A pilot study. J. Periodontol. 2001, 72, 651-658. [CrossRef] [PubMed]

38. Boyne, P.J.; Lilly, L.C.; Marx, R.E.; Moy, P.K.; Nevins, M.; Spagnoli, D.B.; Triplett, R.G. De novo bone induction by recombinant human bone morphogenetic protein-2 (rhBMP-2) in maxillary sinus floor augmentation. J. Oral Maxillofac. Surg. 2005, 63, 1693-1707. [CrossRef] [PubMed]

39. Huh, J.B.; Kim, S.E.; Song, S.K.; Yun, M.J.; Shim, J.S.; Lee, J.Y.; Shin, S.W. The effect of immobilization of heparin and bone morphogenic protein-2 to bovine bone substitute on osteoblast-like cell's function. J. Adv. Prosthodont. 2011, 3, 145-151. [CrossRef] [PubMed]

40. Deligianni, D.D.; Katsala, N.D.; Koutsoukos, P.G.; Missirlis, Y.F. Effect of surface roughness of hydroxyapatite on human bone marrow cell adhesion, proliferation, differentiation and detachment strength. Biomaterials 2001, 22, 87-96. [CrossRef]

41. Jang, J.E.; Kim, H.M.; Kim, H.S.; Jeon, D.Y.; Park, C.H.; Kwon, S.Y.; Chung, J.W.; Khang, G.S. Inflammatory responses to hydroxyapatite/poly (lactic-co-glycolic acid) scaffolds with variation of compositions. Polym. Korea 2014, 38, 156-163. [CrossRef]

(C) 2016 by the authors; licensee MDPI, Basel, Switzerland. This article is an open access article distributed under the terms and conditions of the Creative Commons Attribution (CC-BY) license (http://creativecommons.org/licenses/by/4.0/). 